\title{
Making a Case for Diversion of Solid Medical Waste from Households: A Generation Study in Ga South Municipal Assembly, Accra, Ghana
}

\author{
Emilia A. Udofia', ${ }^{1,2}$, Gabriel Gulis ${ }^{3}$, Julius N. Fobil ${ }^{2}$ \\ ${ }^{1}$ Department of Community Health, School of Public Health, University of Ghana, Legon, Ghana \\ ${ }^{2}$ Department of Biological, Environmental and Occupational Health Sciences, School of Public Health, University of Ghana, \\ Legon, Ghana \\ ${ }^{3}$ Unit for Health Promotion Research, University of Southern Denmark, Esbjerg, Denmark \\ Email: eudofia@ug.edu.gh
}

How to cite this paper: Udofia, E.A., Gulis, G. and Fobil, J.N. (2018) Making a Case for Diversion of Solid Medical Waste from Households: A Generation Study in Ga South Municipal Assembly, Accra, Ghana. Journal of Environmental Protection, 9, 50-66.

https://doi.org/10.4236/jep.2018.91005

Received: December 28, 2017

Accepted: January 23, 2018

Published: January 26, 2018

Copyright $\odot 2018$ by authors and Scientific Research Publishing Inc. This work is licensed under the Creative Commons Attribution International License (CC BY 4.0).

http://creativecommons.org/licenses/by/4.0/

\begin{abstract}
Background: Solid medical waste (SMW) is generated from the healthcare industry but can also be found in households when activity involving patient care occurs. Its hazardous properties require special treatment to minimize hazards to the environment. To achieve this, SMW must be safely diverted from households using a systemic approach, which should be informed by the quantities generated and factors associated with generation. Objective: To characterize household SMW in terms of quantity and composition and to describe the factors associated with its generation. Methods: Manual sorting of household waste was conducted in 60 households to measure quantities of SMW and its components in Ga South Municipal Assembly, Accra, Ghana. Sample collection took place in the wet season (October, 2014) and dry season (December, 2014/January 2015). Rates of generation and percentage composition computed. Factors influencing generation were evaluated with non-parametric tests and quantile regression analysis. Statistical significance was set at $\mathrm{p}<0.05$. Results: Per capita generation of SMW was $1.77 \times 10^{-3}$ $\mathrm{kg} /$ person/day. Pharmaceutical waste and sharps waste comprised $98 \%$ and $2 \%$ of SMW respectively. Generation rates were significantly higher in the wet season than in the dry season $(\mathrm{z}=3.129, \mathrm{p}=0.002)$. Households where medical complaints were reported generated significantly less SMW at the 5th, 10th, 25th and 50th quantiles $(\beta=-2.711, \mathrm{p}=0.001 ; \beta=-2.949 ; \mathrm{p}<0.001$; $\beta=-3.429, \mathrm{p}<0.001 ; \beta=-4.600, \mathrm{p}<0.001$ respectively). Conclusion: SMW was generated in relatively small quantities in households. However, the large proportion of pharmaceuticals with mostly antibiotics raises concerns about drug resistance among other potential hazards.
\end{abstract}




\section{Keywords}

Medical Waste, Ghana, Pharmaceutical Waste, Community

\section{Introduction}

The health care industry generates waste containing pathogens, toxic heavy metals and chemicals, termed healthcare waste (HCW) [1]. The solid component of HCW arising from activities of health protection, diagnosis and treatment is called solid medical waste (SMW) [2]. The traditional domain of SMW is the healthcare industry, where waste is generated from a variety of healthcare activities. However, a limited variety of healthcare activities can also occur in households such as being found in home based care [3] [4], shortened hospital stay [5], care and treatment of chronic diseases in aging populations [6], and home management of illnesses such as malaria [7]. Although SMW constitutes up to $0.1 \%$ of the mixed municipal solid waste stream, its hazardous character attracts public sensitivity and poses a challenge to health and municipal authorities [8]. Examples of SMW found in households include discarded medicines, blood soaked bandages, hypodermic needles and syringes, lancets and insulin pens.

Sharps in the waste stream such as hypodermic needles can cause physical injury and may lead to transmission of blood borne pathogens if present. Expired and unused medicines discarded with household waste, often end up in landfills, where household waste is mostly landfilled. Active pharmaceutical ingredients from discarded medicines in landfills can be discharged into leachate [9]. Environmental hazards associated with pharmaceuticals in SMW include destruction of bacteria necessary for sewage treatment, adverse effects on aquatic and terrestrial life, and air pollution when medicines are burnt at low temperatures [10] [11]. Antibiotic resistance has been demonstrated in viable organisms present in untreated landfill leachate [12]. In Ghana, lack of a waste segregation system in most residential premises suggests that SMW is mixed with household waste. In some cases, final disposal occurs at illegal dumpsites by informal waste porters, who often work without protection. When household waste (HSW) is deposited in poorly maintained landfill sites and unauthorized open dump sites, unrestricted access by scavengers and young children exposes them to community acquired needles tick injuries (CANSIs). Among the reported consequences of this exposure, hepatitis B infection is the most frequently reported, although HIV appears to be the most feared [13] [14].

In recognition of these health hazards, some safety measures have been applied elsewhere. For instance, collection of sharps waste is available for households in some parts of the United States [15] [16] [17]. In Sweden, take-back programs facilitate the return of unwanted medication through pharmacies and even if they were to be discarded in household waste, only $1 \%$ of household waste is land filled [18]. However, similar waste management options do not exist in many developing countries including Ghana. Various studies have demonstrated that 
family and household size [19] [20] [21], household income [19]-[24], and educational status [20] [21] [22] influence household waste generation. Being a component of the household waste stream, these factors could affect generation of SMW. The present study aimed at providing empirical data on the quantity and composition of SMW in households. It also identifies factors associated with generation of SMW.

\section{Methods}

\subsection{Background of the Study Area}

Ga South Municipal Assembly (GSMA) was created in 2009 in south western Accra. It has a total population of 411,377 , of which $48.9 \%$ are males (unpublished document, Ghana Statistical Service, 2014). It is predominantly urban, comprising of towns with populations ranging between 5000 and 20,000. Estate development and commerce have outpaced the earlier agro-based economy (unpublished document, Municipal Planning and Coordinating Unit, 2014). Unpublished reports from the Municipal Assembly Waste Management Department, estimate total solid waste generation at 19.43 tonnes daily, which is managed by public-private partnership.

\subsection{Sample Selection}

A household was the sampling unit in consistency with earlier studies [20] [25] [26]. For waste stream analysis, a minimum of 50 sampling units (households) per 500 households has been suggested by Igbinomwanhia (2011), giving a ratio of 1:10 [27]. On this basis, sixty households were selected from a pre-existing sampling frame of 600 households in October, 2014. In the sampling frame, twenty households each were selected by multi-stage sampling from 30 enumeration areas (EAs) in the municipal assembly during an earlier phase of the field work [28]. Households for the waste stream analysis were selected by ballot. Two households were selected from each of the 30 EAs, making a total of 60 households. Once a household was selected, a member of the household was informed and consent obtained to collect household waste. All households informed accepted to participate in the study.

\subsection{Household Waste Collection}

Identification numbers were assigned to participating households comprising four digits. The first two digits represented their location (numbered 01 to 30) and the second two digits were their serial numbers from the sampling frame (numbered 01 to 20 in each location). Black household bin bags of dimension, $725 \times 975 \mathrm{~mm}$, and 80-litre plastic household bins were labelled with the assigned numbers. Each selected household was informed about the collection schedule ( 6 am to $8 \mathrm{am}$ ), given one bin and two bin bags, and asked to store their waste as routinely done. They were advised to keep the bins covered to prevent stray animals from tampering with the waste. A pilot study conducted a week 
earlier in nine households indicated that daily collection of household waste did not yield meaningful quantities of SMW. Therefore waste collection was conducted weekly in 2 phases that lasted a total of five weeks. The first phase lasted two weeks in October, 2014 (wet season); and the second phase lasted three weeks from December, 2014 to January, 2015 (dry season). New bin bags were provided during waste collection for the following week's collection. Retrieved bin bags with content were transported to a location appointed for manual sorting.

\subsection{Manual Sorting of Household Waste}

The unsorted content of each household's bagged waste was weighed before sorting. To obtain the quantity of specific waste components, manual sorting was undertaken by four trained field staff on a table overlaid with a wire mesh on a clean plastic sheet. The specific waste components were pharmaceutical waste, sharps waste and offensive waste (Table 1).

The waste components were manually sorted and each fraction was weighed. Measurements were estimated on the basis of wet waste (w/w) in kilograms $(\mathrm{kg})$ using a scale GBK 120 with a precision of $0.005 \mathrm{~kg}$ (Adam Equipment Company, 2013) for total household solid waste (HSW) and an additional scale with a capacity of $5 \mathrm{~kg}$ and a precision of $0.001 \mathrm{~kg}$ for household SMW. At the onset of the survey both scales were calibrated against standard weights of 5 Newtons (0.5099 kilograms) and then standardized between measurements. Electronic records were created to store weekly records of waste measurements. Parameters were analysed using the Statistical Package for Social Sciences (SPSS) version 22.

\subsection{Waste Survey}

A waste survey was conducted by four trained data collectors using a purpose designed 32-item questionnaire to obtain respondent and household characteristics. Sociodemographic characteristics were household income, respondent's educational status and room occupancy. Characteristics related to health were: medical complaints, children aged below 5 years in household and National Health Insurance Scheme (NHIS) membership status. The questionnaire was pre-tested and administered in each household, mostly in the evenings. An eligible

Table 1. Sub-classification of solid medical waste in the study.

\begin{tabular}{ccc}
\hline Waste Sub-streams & Description & Examples \\
\hline $\begin{array}{c}\text { Pharmaceutical } \\
\text { waste }\end{array}$ & $\begin{array}{c}\text { Expired, unwanted or left over medicines which were discarded. It also includes } \\
\text { containers contaminated with residue/contents of pharmaceuticals and drug vials. }\end{array}$ & $\begin{array}{c}\text { Syrup bottles, blister packs with } \\
\text { residue/content, drug vials, loose tablets }\end{array}$ \\
Sharps waste & Items that cause cuts or puncture wounds which have been discarded. & Needles, syringes with needles attached, \\
broken glass vials, blades, shaving sticks & & \\
Offensive waste & $\begin{array}{c}\text { Discarded items which have come in contact with body fluid, although not known } \\
\text { to be infectious but causes offense to those who come into contact with it. }\end{array}$
\end{tabular}

a. Solid medical waste comprised pharmaceutical waste and sharps waste; offensive waste was analysed separately. 
respondent was an adult aged 18 years or older who was either well-informed about housekeeping arrangements or resident for at least one month in the household. If there was more than one eligible respondent, selection was done by ballot.

\subsection{Data Management and Analysis}

Descriptive statistics of the sample households were generated. Other variables computed were household daily waste generation rate, per capita daily generation rate, percentage waste weight (\%). Monthly household income was arbitrarily assigned categories based on the range of incomes obtained from the sample (GHC 20 - GHC 900; \$76 - \$236.85). There were three categories: low ( $\leq \mathrm{GHC}$ 200; \$52.63), middle (GHC 201 - GHC 300; \$52.89 - \$78.95) and high income groups (>GHC 300; >\$78.95), somewhat similar to [29], except that the upper limit for the middle income category in [29] was GHC500.

The data were analyzed using non-parametric tests. The Kruskal-Wallis $\mathrm{H}$ test evaluated variation in daily generated quantities of SMW across assigned income groups. Seasonal variation was assumed a priori in household generation of SMW and evaluated with the Wilcoxon signed ranks test. Household characteristics that might influence generation of SMW were determined in two steps. First, within-variable differences in household SMW generation were tested using the Wilcoxon rank sum test. Each characteristic namely medical complaints, National Health Insurance Scheme (NHIS) membership, education, presence of under-fives, type of house and room occupancy, had "1" assigned to the risk category and ' 0 ' to the reference category. A p-value $<0.05$ indicated significant variation in household generation of SMW. In the second step, quantile regression was used for multivariable analysis, applying the statistical model in Equation (1) [30].

$$
Y=\alpha+\sum_{i} \beta_{i} X_{i}+\varepsilon
$$

where $Y$ is the household generation of SMW (kg/household/day), $\alpha$ is a constant term, $\beta_{\mathrm{i}}$ represents the regression coefficient for th household characteristic, $X_{p}$ and the residual error term is represented by $\varepsilon$ [30]. P-values were generated with Stata version 14.0 (Stata Corp College Station, USA), and based on the hypothesis that the computed regression coefficient equals zero. A p-value less than 0.05 implied that variability in household generation of SMW was unlikely to be due to chance.

\section{Results}

\subsection{Participant Characteristics}

Sixty households were recruited for the household waste stream analysis. In this sample, 42 (70.0\%) households were registered under the National Health Insurance Scheme (NHIS), 17 (28.3\%) households reported medical complaints, 23 (38.3\%) households had children aged below 5 years and in 48 (80.0\%) house- 
holds the respondents had attained secondary education or higher. Fifty (83.3\%) households were single (nuclear) families, 27 (45.0\%) households lived in compound houses (multi-unit housing), and 40 (66.7\%) households had 4 sleeping rooms or less. The average household size in the low, middle and high income groups was 4 persons, 5 persons and 4 persons respectively.

\subsection{Solid Medical Waste Generation}

The average quantity of SMW generated in households was $7.26 \times 10^{-3} \mathrm{~kg} /$ household/day and each household member generated $1.77 \times 10^{-3} \mathrm{~kg} /$ person/ day on average (Table 2). Minimum household generation was $0.028 \times 10^{-3} \mathrm{~kg} /$ household/day (28 grams) and maximum household generation was $0.074 \times 10^{-3}$ $\mathrm{kg} /$ household/day (74 grams).

Two households were outliers with generation rates of $54.85 \times 10^{-3} \mathrm{~kg} /$ household/day (household number $=18 / 20$ ) and $74.48 \times 10^{-3} \mathrm{~kg} /$ household $/$ day (household number $=09 / 02$ ) respectively. Both households discarded an unusual quantity of medicines in their household waste for unknown reasons. When these households were excluded, average generation was $5.28 \times 10^{-3}$ $\mathrm{kg} /$ household/day and each household member generated $1.34 \times 10^{-3} \mathrm{~kg} / \mathrm{per}-$ son/day respectively (Table 3 ).

Based on capita generation and population size in the 30 locations $(\mathrm{n}=24,183)$, the average daily quantity of SMW generated was $42.80 \mathrm{~kg}$ when outlier measurements were included and $32.40 \mathrm{~kg}$, when they were excluded. No significant variation was found in SMW generated across the income groups per household $[\mathrm{H}(2)=1.40, \mathrm{p}=0.497]$ and per capita $[\mathrm{H}(2)=3.08, \mathrm{p}=0.214]$.

\subsection{Percentage Composition of Waste Sub-Streams in the Household Waste Stream}

During the study period, the average percentage composition of SMW in

Table 2. Descriptive statistics for solid medical waste generation per household (kg/hh/ day) and per capita generation (kg/person/day).

\begin{tabular}{ccc}
\hline Name of parameters & $\begin{array}{c}\text { Household generation } \\
(\mathrm{kg} / \mathrm{hh} / \text { day })\end{array}$ & $\begin{array}{c}\text { Per capita generation } \\
(\mathrm{kg} / \text { person/day })\end{array}$ \\
\hline $\begin{array}{c}\text { Mean } \\
(\mathrm{n}=60 \text { households })\end{array}$ & $7.26 \times 10^{-3}$ & $1.77 \times 10^{-3}$ \\
Standard deviation & $11.58 \times 10^{-3}$ & $2.64 \times 10^{-3}$ \\
Coefficient of variation & 1.60 & 1.49 \\
Median & $4.59 \times 10^{-3}$ & $1.05 \times 10^{-3}$ \\
Interquartile range & $4.85 \times 10^{-3}$ & $1.18 \times 10^{-3}$ \\
Minimum & $28.6 \times 10^{-6}$ & $8.16 \times 10^{-6}$ \\
(household number $=01 / 05)$ & $0.74 \times 10^{-3}$ & $0.15 \times 10^{-3}$ \\
Maximum & 4.51 & 3.72 \\
(household number $=09 / 02)$ & 24.52 & 17.87 \\
Coefficient of skewness & & \\
Coefficient of kurtosis & &
\end{tabular}


Table 3. Descriptive statistics for solid medical waste generation per household $\left(\mathrm{kg} / \mathrm{hh} /\right.$ day) and per capita generation $\left(\mathrm{kg} /\right.$ person/day) without outliers ${ }^{\mathrm{a}}$.

\begin{tabular}{ccc}
\hline Name of parameters & $\begin{array}{c}\text { Household generation } \\
(\mathrm{kg} / \mathrm{hh} / \text { day })\end{array}$ & $\begin{array}{c}\text { Per capita generation } \\
(\mathrm{kg} / \text { person/day })\end{array}$ \\
\hline $\begin{array}{c}\text { Mean } \\
(\mathrm{n}=58 \text { households })\end{array}$ & $5.28 \times 10^{-3}$ & $1.34 \times 10^{-3}$ \\
$\begin{array}{c}\text { Standard deviation } \\
\text { Coefficient of variation }\end{array}$ & $3.98 \times 10^{-3}$ & $1.23 \times 10^{-3}$ \\
Median & 0.75 & 0.92 \\
$\begin{array}{c}\text { Interquartile range } \\
\text { Minimum }\end{array}$ & $4.38 \times 10^{-3}$ & $1.01 \times 10^{-3}$ \\
(household number $=01 / 05)$ & $4.71 \times 10^{-3}$ & $1.05 \times 10^{-3}$ \\
Maximum & $28.6 \times 10^{-6}$ & $8.16 \times 10^{-6}$ \\
(household number $=02 / 03)$ & $1.72 \times 10^{-2}$ & $0.57 \times 10^{-2}$ \\
Coefficient of skewness & 1.18 & 1.60 \\
Coefficient of kurtosis & 4.10 & 5.41 \\
\hline
\end{tabular}

a. Two households were excluded from the original sample in Table 2 (household numbers 18/20 and 09/02 with household generation rates of $54.85 \times 10^{-3} \mathrm{~kg} /$ household/day and $74.48 \times 10^{-3} \mathrm{~kg} / \mathrm{household} /$ day respectively).

household waste was $1.07 \%$ (offensive waste excluded). Pharmaceutical waste formed the bulk (approximately 98\%) of SMW from households. The percentage distribution of sharps waste was similar across income groups. When all income groups were combined, the percentage of pharmaceutical waste, sharps waste and offensive waste in household waste were $1.05 \%, 0.02 \%$ and $4.94 \%$ respectively.

\subsection{Seasonal Variation in Generation Rates of Waste Sub-Streams}

When all income groups were combined, the per capita daily generation rates were significantly higher in the wet season than in the dry season for pharmaceutical waste, solid medical waste and offensive waste. Sharps waste showed no seasonal variation $(\mathrm{z}=1.938, \mathrm{p}=0.053)$ (Table 4$)$.

\subsection{Factors Associated with Quantity of Solid Medical Waste}

Preliminary analysis showed that medical complaints, type of house, and room occupancy might influence the distribution of SMW (Table 5).

After multivariable analysis, reported medical complaints emerged as the only significant factor influencing generation of SMW. Households that reported medical complaints generated significantly less SMW than households that did not report medical complaints, controlling for type of house and room occupancy (Table 6). The greatest difference was observed at the 75th quantile, when outliers were excluded $(\beta=-5.107 ; \mathrm{p}=0.005)($ Table 7$)$.

\subsection{Description of SMW Recovered from Household Waste}

Among items recovered from pharmaceutical waste, antibiotics, multivitamins, 
Table 4. Per capita generation of waste components (kg/person/day) distributed by season ( $\mathrm{n}=60$ households).

\begin{tabular}{|c|c|c|c|c|c|c|c|c|c|c|}
\hline \multirow{2}{*}{$\begin{array}{c}\text { SMW } \\
\text { components } \backslash \\
\text { Income group }\end{array}$} & \multicolumn{2}{|c|}{ Low income } & \multicolumn{2}{|c|}{ Middle income } & \multicolumn{2}{|c|}{ High income } & \multicolumn{2}{|c|}{ Total } & \multicolumn{2}{|c|}{$\begin{array}{c}\text { Wilcoxon signed rank } \\
\text { test }\end{array}$} \\
\hline & Wet season & Dry season & Wet season & Dry season & Wet season & Dry season & Wet season & Dry season & $\mathrm{Z}$ & p-value ${ }^{b}$ \\
\hline $\begin{array}{c}\text { Pharmaceutical } \\
\text { waste }\end{array}$ & $4.31 \times 10^{-3}$ & $1.10 \times 10^{-3}$ & $0.81 \times 10^{-3}$ & $1.06 \times 10^{-3}$ & $1.97 \times 10^{-3}$ & $0.98 \times 10^{-3}$ & $2.79 \times 10^{-3}$ & $1.06 \times 10^{-3}$ & 3.052 & 0.002 \\
\hline Sharps waste & $0.06 \times 10^{-3}$ & $0.04 \times 10^{-3}$ & $0.05 \times 10^{-3}$ & $0.03 \times 10^{-3}$ & $0.04 \times 10^{-3}$ & $0.03 \times 10^{-3}$ & $0.05 \times 10^{-3}$ & $0.04 \times 10^{-3}$ & 1.938 & 0.053 \\
\hline $\begin{array}{l}\text { Solid medical } \\
\text { waste }\end{array}$ & $4.36 \times 10^{-3}$ & $1.15 \times 10^{-3}$ & $0.87 \times 10^{-3}$ & $1.07 \times 10^{-3}$ & $2.01 \times 10^{-3}$ & $1.01 \times 10^{-3}$ & $2.84 \times 10^{-3}$ & $1.09 \times 10^{-3}$ & 3.129 & 0.002 \\
\hline Offensive waste & $34.89 \times 10^{-3}$ & $10.65 \times 10^{-3}$ & $38.86 \times 10^{-3}$ & $10.28 \times 10^{-3}$ & $14.28 \times 10^{-3}$ & $2.90 \times 10^{-3}$ & $30.97 \times 10^{-3}$ & $8.61 \times 10^{-3}$ & 4.960 & 0.000 \\
\hline
\end{tabular}

${ }^{a}$ Values under wet and dry season are in $\mathrm{kg} /$ person/day. ${ }^{\mathrm{b}} \mathrm{p}$-values in bold font are statistically significant at $5 \%$ significance level.

Table 5. Solid medical waste (kg/household/day) by household characteristics based on Two-sample Wilcoxon rank-sum (Mann-Whitney) test.

\begin{tabular}{|c|c|c|c|}
\hline Characteristics & $\begin{array}{l}\text { Median quantity of solid } \\
\text { medical waste (IQR) }\end{array}$ & $\begin{array}{c}\text { Mann-Whitney } \\
\text { test statistic }\end{array}$ & $\mathrm{p}$-value $\mathrm{b}^{\mathrm{b}}$ \\
\hline \multicolumn{4}{|l|}{ NHIS } \\
\hline No & $3.80 \times 10^{-3}\left(4.71 \times 10^{-3}\right)$ & -0.008 & 0.994 \\
\hline Yes & $4.80 \times 10^{-3}\left(5.08 \times 10^{-3}\right)$ & & \\
\hline \multicolumn{4}{|l|}{ Medical Complaints } \\
\hline No & $5.86 \times 10^{-3}\left(4.80 \times 10^{-3}\right)$ & 3.986 & 0.000 \\
\hline Yes & $2.31 \times 10^{-3}\left(1.89 \times 10^{-3}\right)$ & & \\
\hline \multicolumn{4}{|l|}{ Highest level of education } \\
\hline None/Basic & $3.81 \times 10^{-3}\left(4.33 \times 10^{-3}\right)$ & 0.213 & 0.832 \\
\hline Secondary or higher & $4.80 \times 10^{-3}\left(5.09 \times 10^{-3}\right)$ & & \\
\hline \multicolumn{4}{|c|}{ Children aged below 5 years } \\
\hline Yes & $3.89 \times 10^{-3}\left(3.17 \times 10^{-3}\right)$ & 0.395 & 0.693 \\
\hline No & $4.71 \times 10^{-3}\left(5.65 \times 10^{-3}\right)$ & & \\
\hline \multicolumn{4}{|l|}{ Type of House } \\
\hline Compound house & $3.51 \times 10^{-3}\left(3.12 \times 10^{-3}\right)$ & 2.244 & 0.025 \\
\hline Flat/Other & $5.94 \times 10^{-3}\left(6.88 \times 10^{-3}\right)$ & & \\
\hline \multicolumn{4}{|c|}{ Room occupancy (category) } \\
\hline$\leq 2$ person(s) per room & $5.28 \times 10^{-3}\left(5.02 \times 10^{-3}\right)$ & 2.038 & 0.042 \\
\hline$>2$ persons per room & $2.66 \times 10^{-3}\left(1.72 \times 10^{-3}\right)$ & & \\
\hline \multicolumn{4}{|l|}{ Family type } \\
\hline Single family & $4.67 \times 10^{-3}\left(4.71 \times 10^{-3}\right)$ & 0.615 & 0.539 \\
\hline $\begin{array}{l}\text { Extended } \\
\text { family }\end{array}$ & $3.73 \times 10^{-3}\left(5.29 \times 10^{-3}\right)$ & & \\
\hline
\end{tabular}

a. IQR is the interquartile range. b. p-values in bold font are statistically significant at $5 \%$ level of significance.

analgesics, antifungal and antimalarial drugs were present, with antibiotics being predominant. For instance, syrup bottles containing amoxicillin and metronidazole (mostly as paediatric formulation), capsules of ampicillin, cloxacillin, doxycycline, and penicillin $\mathrm{V}$ tablets were found. Non-steroidal anti-inflammatory drugs (NSAIDs) included diclofenac and ibuprofen. Paracetamol was found 
Table 6. Regression coefficients ${ }^{\mathrm{a}}$ of household characteristics, by OLS and by Quantiles and their respective $\mathrm{p}$-values ${ }^{\mathrm{b}}$ ( $\mathrm{n}=60$ households).

\begin{tabular}{ccccccccc}
\hline Variable & OLS & $\mathrm{q} 05$ & $\mathrm{q} 10$ & $\mathrm{q} 25$ & $\mathrm{q} 50$ & $\mathrm{q75}$ & $\mathrm{q} 90$ & $\mathrm{q} 95$ \\
\hline $\begin{array}{c}\text { constant } \\
\text { p-value }\end{array}$ & 9.086 & 2.720 & 3.149 & 4.286 & 7.149 & 8.486 & 13.371 & 15.829 \\
$\begin{array}{c}\text { Medical } \\
\text { complaints }\end{array}$ & -5.935 & -2.711 & -2.949 & -3.429 & -4.600 & -2.943 & -4.914 & -10.200 \\
$\begin{array}{c}\text { p-value } \\
\text { Type of }\end{array}$ & 0.076 & $\mathbf{0 . 0 0 1}$ & $\mathbf{0 . 0 0 0}$ & $\mathbf{0 . 0 0 0}$ & $\mathbf{0 . 0 0 0}$ & 0.177 & 0.668 & 0.610 \\
$\begin{array}{c}\text { house } \\
\text { p-value }\end{array}$ & 0.013 & 0.019 & -0.171 & -0.771 & -1.292 & -0.169 & 3.857 & 9.143 \\
$\begin{array}{c}\text { Room } \\
\text { occupancy } \\
\text { (category) }\end{array}$ & -5.152 & -1.168 & -1.406 & -1.594 & -3.429 & -2.711 & -9.651 & -12.108 \\
p-value & 0.276 & 0.176 & 0.012 & 0.141 & 0.056 & 0.312 & 0.365 & 0.406 \\
$\mathrm{R}^{2 c}$ & 0.0756 & 0.1581 & 0.1645 & 0.1208 & 0.1010 & 0.0752 & 0.0769 & 0.0890 \\
\hline
\end{tabular}

a. All coefficient values for the study attributes are multiplied by $\left(\times 10^{-3}\right)$. b. The probability values ( $\mathrm{p}$-value) support the hypothesis that the computed coefficient equals zero. A p-value of 0.05 or less indicates a statistically significant effect at $5 \%$ significance level. c. The coefficient of determination (R2) in quantile regression models are Pseudo R2.

Table 7. Regression coefficients ${ }^{\mathrm{a}}$ of household characteristics, by OLS and by Quantiles and their respective $\mathrm{p}$-values ${ }^{\mathrm{b}}$ ( $\mathrm{n}=58$ households).

\begin{tabular}{ccccccccc}
\hline Variable & OLS & q05 & q10 & q25 & q50 & q75 & q90 & q95 \\
\hline constant & 6.343 & 0.857 & 2.720 & 3.488 & 6.628 & 7.971 & 11.568 & 13.371 \\
p-value & 0.000 & 0.391 & 0.005 & 0.000 & 0.000 & 0.000 & 0.000 & 0.000 \\
$\begin{array}{c}\text { Medical } \\
\text { complaints }\end{array}$ & -3.236 & -0.771 & -2.006 & -2.631 & -4.318 & -5.107 & -5.940 & -2.457 \\
$\begin{array}{c}\text { p-value } \\
\text { Type of } \\
\text { house }\end{array}$ & $\mathbf{0 . 0 0 5}$ & 0.406 & $\mathbf{0 . 0 3 0}$ & $\mathbf{0 . 0 0 1}$ & $\mathbf{0 . 0 0 1}$ & $\mathbf{0 . 0 0 5}$ & 0.154 & 0.666 \\
$\begin{array}{c}\text { p-value } \\
\text { Room }\end{array}$ & 0.465 & 0.914 & 0.318 & 0.322 & 0.266 & 0.281 & 0.380 & 0.480 \\
$\begin{array}{c}\text { occupancy } \\
\text { (category) }\end{array}$ & 0.525 & 1.229 & -0.029 & 0.403 & 0.320 & 1.621 & 2.546 & 0.743 \\
p-value & 0.634 & 0.214 & 0.973 & 0.614 & 0.776 & 0.342 & 0.488 & 0.868 \\
$\mathrm{R}^{2 c}$ & 0.1523 & 0.1824 & 0.1817 & 0.1559 & 0.1306 & 0.1106 & 0.1035 & 0.0695 \\
\hline
\end{tabular}

a. All coefficient values for the study attributes are multiplied by $\left(\times 10^{-3}\right)$. b. The probability values ( $\mathrm{p}$-value) support the hypothesis that the computed coefficient equals zero. A p-value of 0.05 or less indicates a statistically significant effect at $5 \%$ significance level. c. The coefficient of determination (R2) in quantile regression models are Pseudo R2.

in dispensing envelopes, blister packs and as loose tablets. Antihypertensive (nifedipine, lisinopril, amlodipine, bendrofluazide) and antidiabetic (glibenclamide, metformin) medicines were also present in blister packs or dispensing envelopes. Sharps recovered were predominantly used razor blades. A few disposable shaving sticks were also present. Needles (capped and uncapped) and syringes were recovered from a single household bin bag. Offensive waste mostly comprised of 
soiled baby diapers, with a smaller fraction of blood stained tissue paper, sanitary pads and cotton buds. Other items found in single disposal events included plaster, a long wrap of gauze bandage soiled with serous fluid and a pair of examination gloves. Male condoms and intravenous infusion bags (normal saline) were found on two disposal events. No intravenous tubing or cannulae were seen.

\section{Discussion}

\subsection{Generation of Solid Medical Waste in Households}

At the time of writing, no study had described the quantification of SMW in household solid waste in Ghana, therefore our study represents the first generation study conducted in a local community. Households typically generated between 5 and 7 grams of SMW daily. Although these were relatively small amounts, the total daily production of $32.40 \mathrm{~kg}$ computed for the study population is substantial. With the outlier households, the daily production of $42.80 \mathrm{~kg}$ represents situations where hoarding of medicines may occur in the household. This could result in periodic or one-off disposal of large quantities of SMW. The small sample of households used in the study suggests that the values are indicative, but its composition mostly of unwanted medicines, especially antibiotics raises concern. This is given the fact that nearly all household waste in Ghana is sent to landfills.

Household generation of SMW showed significant seasonal variation. This confirmed our assumption a priori. Some diseases that exhibit seasonal variation often require the use of medicines, such as malaria and respiratory tract infections. This would result in the generation of SMW from left over or expired medicines. Waste generated would include medicines and/or their containers, but not packaging. The higher generation of SMW in the wet season may be partly attributed to common acute illnesses which tend to peak with the rains, such as malaria, respiratory tract infections and some diarrhoeal diseases. The medicines recovered during the waste stream analysis included therapeutic categories often prescribed or bought over the counter for these conditions. Therefore, the consumption of medicines may be higher in these seasons and left over medicines and their containers generate SMW. It is also possible that at the onset of the survey which was in the wet season, a few households may have utilized the opportunity to discard stored waste items since waste collection was offered at no cost to households, whereas the services rendered by the waste management companies had to be paid for monthly. However, these outliers were limited to less than $5 \%$ of the sampled households.

Cussiol et al. (2006) sampled municipal solid waste (mostly of residential origin) to quantify potentially infectious waste [31]. Therefore we compared our results with this study. Unwanted medicines referred to as 'chemical waste', accounted for $1.91 \%$ of the waste sample in the reference study. We found a lower proportion of $1.05 \%$. It is likely that SMW from other sources may partly account for differences observed in waste composition between the reference study 
and the present study. The proportion of sharps waste was similar in both studies. However, a lower percentage of non-sharps (offensive) waste was generated in the present study, $4.94 \%$ compared to $5.47 \%$ in the reference study. The higher proportion of offensive waste was mostly attributed to baby diapers which formed the bulk of waste in both cases.

\subsection{Potential Hazards to Health and Environment}

Unwanted medicines comprised the bulk of SMW in households. The therapeutic categories of the medicines recovered were consistent with acute and chronic diseases prevalent in Ghana. Acute conditions such as malaria, respiratory infections and diarrhoea [32] are prevalent, as well as chronic conditions, such as hypertension [33] [34] and diabetes mellitus [35] [36]. Syrup bottles labelled with antimalarial, antibiotic and multi-vitamin preparations, were found with minimal residue or some content left over from previous use. As household waste is mostly deposited in landfills and open dumps, such disposal practices can potentially introduce active pharmaceutical ingredients in the environment. The greatest concern is the risk of antibiotic resistance as antibiotics were the largest category of medicines recovered from household waste, particularly the penicillin group. In a similar study of municipal solid waste in Florida, USA, antibiotics as a group was found in the largest quantity, followed by non-steroidal anti-inflammatory drugs [37]. Diclofenac and ibruprofen have been reported in earlier studies to be associated with toxic effects in birds [38], in aquatic life [39] and reduces survival of decomposers [40]. Razor blades were the most common type of sharps waste, as also reported in the study by Cussiol et al. (2006) [31]. The presence of needles found loosely in household waste confers hazardous properties on the household waste stream. Hollow needles present in waste predispose waste workers and other persons handling the waste to community acquired needle stick injuries.

Offensive waste is not considered medical waste, but deserves mention because it accounted for a higher overall percentage of household waste $(4.94 \%)$ compared to SMW (1.07\%); and it was often soiled with faecal matter or body fluids. Faecally soiled diapers and used sanitary pads were recovered from the household waste stream analysis, with the former in large quantities. Faecally soiled materials can contain enteric pathogens such as E. coli, Salmonella, and Shigella, which have been reported to survive up to 117 kilometres from source when introduced into flowing water [41] [42]. These agents can cause diarrhoeal diseases in exposed persons through orofaecal transmission. Elsewhere it has been reported that polio and echoviruses were isolated from $11 \%$ of faecally soiled diapers [43]. Another study reported the recovery of human papilloma virus from menstrual fluid or vaginal discharge collected in sanitary napkins, although these napkins were not retrieved from waste [44]. The precautionary principle, the potential of microbes to multiply under favourable storage conditions offered by household waste and the non-use or lack of adequate protection 
by waste workers and scavengers in developing countries posits offensive waste as potentially infectious in these settings [1].

\subsection{Strengths of the Study}

This study presents a quantitative and qualitative description of household SMW in a district in Ghana. Only a few studies in Africa have reported on SMW in the community and these often lack quantitative estimates. Empirical data in this study, though indicative, provide baseline data for further generation studies and informs waste management in the district. If SMW should be segregated at source and diverted from the household waste stream, storage and transport capacities can be computed. It draws attention to the large proportion of SMW comprising mostly pharmaceutical waste (mostly antibiotics and non-steroidal anti-inflammatory steroidal drugs) sent to landfills and raises concerns about potential antibiotic resistance and toxicity to wildlife.

\subsection{Limitations of the Study}

At the onset of the study, some of the households did not place their household waste for collection as agreed. This changed and collection improved in the later weeks. To compensate for these events, single mean imputation for missing data was used to compute the missing weight measurements in Stata version 14.0 (StataCorp LP, Lakeway Drive, Texas, USA).

Due to the small sample size of households for the waste stream analysis, results can only be considered indicative. To obtain quantitative estimates intended for regional planning, larger samples taken over successive surveys are recommended. The non-normal distribution of weight measurements of SMW is due to its generation in relatively smaller quantities compared to healthcare facilities. The clustering of measurements close to zero, and fewer extreme values often resulted in a positive skew. The weight of the medicine containers might have affected the weight of SMW, however these were not disregarded as residue left in them can contain active ingredients. Finally, the assignment of income groups arbitrarily, limits the generalization of the results beyond the study location.

\subsection{Conclusion and Recommendations}

Generation of SMW is influenced by medical complaints and is higher in the wet season than in the dry season. As SMW comprised largely of pharmaceuticals, segregation at source could divert this sub-stream for appropriate treatment and disposal to minimize any potential environmental and/or health impact. The relatively smaller quantities of sharps confer some hazardous properties on household waste and should be safely diverted from the waste stream. The impact of continual deposits of SMW generated at computed rates in the study area is unknown, but extant literature and waste composition rationalize concerns about antibiotic resistance and toxicity to wildlife. Therefore, it is pertinent that future policy on the management of SMW takes into account quantities gener- 
ated in the community, rather than focus on healthcare institutions alone.

\section{Declarations}

\section{Ethical Considerations and Clearance to Conduct the Study}

Ethical approval for the study was obtained from the Noguchi Memorial Institute of Medical Research (NMIMR) Institutional Research Board. Written permission to conduct the study was obtained from the Municipal Chief Executive (MCE). Clearance was obtained verbally from community chiefs during a meeting convened by GSMA. At the meeting, the purpose of the study and the stages in the study were briefly explained. Individual informed consent was obtained from all persons prior to questionnaire administration. Respondents were interviewed in the privacy of their homes and only eligible households participated in the study. Participants' rights to withdrawal from the study were upheld and all participants were treated with respect.

\section{Competing Interests}

All authors declare that they have no competing interests.

\section{Funding}

The funding for this research came from a $\mathrm{PhD}$ fellowship grant awarded to EAU by Building Stronger Universities in Developing Countries-Platform for Human Health of the Danish Government, in collaboration with the University of Ghana. Other than training in basic research methods and proposal development, the funders played no further role in this research.

\section{Authors' Contributions}

EAU conceived, designed and analyzed the study. Methodology was reviewed by GG and JNF. Data collection was coordinated by EAU. All authors made significant contributions to the writing of the manuscript. The final manuscript was reviewed and approved by all authors.

\section{Acknowledgements}

The authors gratefully acknowledge the Building Stronger Universities in Developing Countries-Platform for Human Health, DANIDA and the University of Ghana, which provided funding for the larger study of which this study is a part. We are also grateful to the Ga South Municipal Assembly, its Health Directorate, Chiefs, communities and the field staff for their support during the conduct of the study.

\section{References}

[1] WHO (2014) Definition and Characterization of Health-Care Waste. In: Chartier, Y., et al., Eds., Safe Management of Wastes from Health-Care Activities, 2nd Edition, World Health Organization Press, Geneva, 3-23. 
[2] Klangsin, P. and Harding, A.K. (1998) Medical Waste Treatment and Disposal Methods Used by Hospitals in Oregon, Washington, and Idaho. Journal of the Air \& Waste Management Association, 48, 516-526. https://doi.org/10.1080/10473289.1998.10463706

[3] Phorano, O.M., Nthomang, K. and Ngwenya, B.N. (2005) HIV/AIDS, Home Care and Human Waste Disposal in Botswana. Botswana Society Notes and Records, Special Edition on Human Interactions and Natural Resource Dynamics in the Okavango Delta and Ngamiland, 37, 161-178.

[4] Kang'ethe, S.M. (2008) Clinical Waste Management in the Context of the Kanye Community Home-Based Care Programme, Botswana. African Journal of AIDS Research, 7, 187-194. https://doi.org/10.2989/AJAR.2008.7.2.4.521

[5] Weisfeld, V. and Lustig, T.A. (2015) The Future of Home Health Care: Workshop Summary. The National Academies Press, Washington DC.

http://www.nap.edu?catalog.php?record_id=21662

[6] Oyewole, A., Sapp, J., Wilson, B. and Oyewole, O. (2014) Potential Environmental Risk from Home Health-Care Generated Municipal Solid Waste in Texas. International Journal of Business, Humanities and Technology, 4, 6-12.

[7] Chinbuah, M.A., Kager, P.A., Abbey, M., Gyapong, M., Awini, E., Nonvignon, J., et al. (2012) Impact of Community Management of Fever (Using Antimalarials with or without Antibiotics) on Childhood Mortality: A Cluster-Randomized Controlled Trial in Ghana. The American Journal of Tropical Medicine and Hygiene, 87, 11-20. https://doi.org/10.4269/ajtmh.2012.12-0078

[8] Yordanova, D., Angelova, S., Kyoseva, V. and Dombalov, I. (2014) Household Medical Waste-Threat to the Environment and Human Health. Journal of Chemical Technology and Metallurgy, 49, 185-188.

[9] Kummerer, K. (2009) The Presence of Pharmaceuticals in the Environment Due to Human Use-Present Knowledge and Future Challenges. J Environ Manage, 90, 2354-2366. https://doi.org/10.1016/j.jenvman.2009.01.023

[10] Vogler, S.L.C, Zuidberg, C. and Habl, C. (2014) Medicines Discarded in Household Garbage: Analysis of a Pharamaceutical Sample in Vienna. Journal of Pharmaceutical Policy and Practice, 7, 6.

[11] Vellinga, A., Cormican, S., Driscoll, J., Furey, M., O’Sullivan, M. and Cormican, M. (2014) Public Practice Regarding Disposal of Unused Medicines in Ireland. Science of the Total Environment, 478, 98-102. https://doi.org/10.1016/j.scitotenv.2014.01.085

[12] Nascimento, T.C., da Silva, V.L., Ferreira-Machado, A.B. and Diniz, C.G. (2015) Potential Spread of Multi-Drug Resistant Coagulase-Negative Staphylococci through Healthcare Waste. The Journal of Infection in Developing Countries, 9, 29-34. https://doi.org/10.3855/jidc.4563

[13] Jason, J. (2013) Community-Acquired, Non-Occupational Needlestick Injuries Treated in US Emergency Departments. Journal of Public Health, 35, 422-430. https://doi.org/10.1093/pubmed/fdt033

[14] Osowiki, J. and Curtis, N. (2014) Question 2: A Pointed Question: Is a Child at Risk following a Community Acquired Needlestick Injury? Archives of Disease in Childhood, 99, 1172-1175. https://doi.org/10.1136/archdischild-2014-306929

[15] Derflinger, B.B. and Druckenmiller, J.K. (2002) How Wisconsin Promotes Household Sharps Collection. Journal of the American Pharmacists Association, 42, S111-S112. https://doi.org/10.1331/1086-5802.42.0.S111.Derflinger

[16] Turnberg, W.L., Coulter, E., Clark, J.R. and Vincent, R.G. (2002) Community 
Needle Collection and Disposal Programs in Florida. Journal of the American Pharmacists Association, 42, S108-S109.

[17] Markkanen, P., Galligan, C., Laramie, A., Fisher, J., Sama, S. and Quinn, M. (2015) Understanding Sharps Injuries in Home Healthcare: The Safe Home Care Qualitative Methods Study to Identify Pathways for Injury Prevention. BMC Public Health, 15, 359. https://doi.org/10.1186/s12889-015-1673-x

[18] Avfall Sverige (2014) Swedish Waste Management.

[19] Salam, M.A., Hossain, M.L., Das, S.R., Wahab, R. and Hossain, M.K. (2012) Generation and Assessing the Composition of Household Solid Waste in Commercial Capital City of Bangladesh. International Journal of Environmental Science, Management and Engineering Research, 1, 160-171.

[20] Qu, X.-Y., Li, Z.-S., Xie, X.-Y., Sui, Y.-M., Yang, L. and Chen, Y. (2009) Survey of Composition and Generation Rate of Household Wastes in Beijing, China. Waste Management, 29, 2618-2624. https://doi.org/10.1016/j.wasman.2009.05.014

[21] Sajauddin, M., Huda, S.M. and Hoque, A.T. (2008) Household Solid Waste Characteristics and Management in Chittagong, Bangladesh. Waste Management, 28, 1688-1695. https://doi.org/10.1016/j.wasman.2007.06.013

[22] Monavari, S.M., Omrani, G.A., Karbassi, A. and Raof, F.F. (2012) The Effects of Socioeconomic Parameters on Household Solid-Waste Generation and Composition in Developing Countries (A Case Study: Ahvaz, Iran). Environmental Monitoring and Assessment, 184, 1841-1846. https://doi.org/10.1007/s10661-011-2082-y

[23] Dangi, M.B., Urynowicz, M.A., Gerow, K.G. and Thapa, R.B. (2008) Use of Stratified Cluster Sampling for Efficient Estimation of Solid Waste Generation at Household Level. Waste Management \& Research, 26, 493-499. https://doi.org/10.1177/0734242X07085755

[24] Alias, F.S., Manaf, L.A., Ho Abdullah, S.J. and Nyuk Onn, M.H. (2014) Solid Waste Generation and Composition at Water Villages in Sabah, Malaysia. Polish Journal of Environmental Studies, 23, 1475-1481.

[25] Salam, M.A., Hossain, M.L., Das, S.R., Wahab, R. and Hossain, M.K. (2012) Generation and Assessing the Composition of Household Solid Waste in Commercial Capital City of Bangladesh. International Journal of Environmental Science, Management and Engineering Research, 1, 160-171.

[26] Monney, I., Tiimub, B.M. and Bagah, H.C. (2013) Characteristics and Management of Household Solid Waste in Urban Areas in Ghana: The Case of WA. Civil and Environmental Research, 3, 10-21.

[27] Igbinomwanhia, D.I. (2011) Status of Waste of Management. In: Kumar, S., Ed., Integrated Waste Management, Volume 2, InTech Open Access Publisher, 11-34. http://www.intechopen.com/books/integrated-waste-management-volume-ii/status -of-waste-management

[28] WHO (2008) Training for Mid-Level Managers (MLM)-Module 7: The EPI Coverage Survey. Department of Immunization, Vaccines and Biologicals, WHO, Geneva, 10-17.

[29] Addo, H.O., Dun-Dery, E.J., Afoakwa, E., Elizabeth, A., Ellen, A. and Rebecca, M. (2017) Correlates of Domestic Waste Management and Related Health Outcomes in Sunyani, Ghana: A Protocol towards Enhancing Policy. BMC Public Health, 17, 615. https://doi.org/10.1186/s12889-017-4537-8

[30] Zietz, J., Zietz, E.N. and Sirmans, G.S. (2008) Determinants of House Prices: A Quantile Regression Approach. The Journal of Real Estate Finance and Economics, 37, 317-333. https://doi.org/10.1007/s11146-007-9053-7 
[31] Cussiol, N.A., Rocha, G.H. and Lange, L.C. (2006) Gravimetric Characterization of Potentially Infectious Material in Urban Solid Waste in Southern Belo Horizonte, Minas Gerais State, Brazil. Cadernos de Saúde Pública, 22, 1183-1191.

https://doi.org/10.1590/S0102-311X2006000600007

[32] Fink, G., Weeks, J.R. and Hill, A.G. (2012) Income and Health in Accra, Ghana: Results from a Time Use and Health Study. The American Journal of Tropical Medicine and Hygiene, 87, 608-615. https://doi.org/10.4269/ajtmh.2012.12-0062

[33] de-Graft Aikins, A., Kushitor, M., Koram, K., Gyamfi, S. and Ogedegbe, G. (2014) Chronic Non-Communicable Diseases and the Challenge of Universal Health Coverage: Insights from Community-Based Cardiovascular Disease Research in Urban Poor Communities in Accra, Ghana. BMC Public Health, 14, S3. https://doi.org/10.1186/1471-2458-14-S2-S3

[34] Bosu, W.K. (2010) Epidemic of Hypertension in Ghana: A Systematic Review. BMC Public Health, 10, Article 418. https://doi.org/10.1186/1471-2458-10-418

[35] Amoah, A.G., Owusu, S.K. and Adjei, S. (2002) Diabetes in Ghana: A Community Based Prevalence Study in Greater Accra. Diabetes Research and Clinical Practice, 56, 197-205. https://doi.org/10.1016/S0168-8227(01)00374-6

[36] Danquah, I., Bedu-Addo, G., Terpe, K.-J., Micah, F., Amoako, Y.A., Awuku, Y.A., et al. (2012) Diabetes Mellitus Type 2 in Urban Ghana: Characteristics and Associated Factors. BMC Public Health, 12, 210. https://doi.org/10.1186/1471-2458-12-210

[37] Musson, S.E. and Townsend, T.G. (2009) Pharmaceutical Compound Content of Municipal Solid Waste. Journal of Hazardous Materials, 162, 730-735. https://doi.org/10.1016/j.jhazmat.2008.05.089

[38] Oaks, J.L., Gilbert, M., Virani, M.Z., et al. (2004) Diclofenac Residues as the Cause of Vulture Population Decline in Pakistan. Nature, 427, 630-633. https://doi.org/10.1038/nature02317

[39] Flippin, J.L., Huggett, D. and Foran, C.M. (2007) Changes in the Timing of Reproduction following Chronic Exposure to Ibuprofen in Japanese Medaka, Oryzias latipes. Aquatic Toxicology, 81, 73-78. https://doi.org/10.1016/j.aquatox.2006.11.002

[40] Chen, G., den Brauer, M.W., van Gestel, C.A., van Straalen, N.M. and Roelofs, D. (2015) Ecotoxigenomic Assessment of Diclofenac Toxicity in Soil. Environmental Pollution, 199, 253-260. https://doi.org/10.1016/j.envpol.2015.01.032

[41] Peterson, M.L. (1974) Soiled Disposable Diapers: A Potential Source of Viruses. American Journal of Public Health, 64, 912-914. https://doi.org/10.2105/AJPH.64.9.912

[42] Tong, T.R., Chan, O.W.H., Chow, T.-C., Yu, V., Leung, K.-M. and To, S.-H. (2003) Detection of Human Papillomavirus in Sanitary Napkins: A New Paradigm in Cervical Cancer Screening. Diagnostic Cytopathology, 28, 140-141. https://doi.org/10.1002/dc.10255

[43] Manson, C. (1991) The Biology of Fresh Water Pollution. John Wiley and Sons, New York.

[44] Mangizvo, R.V. (2014) The Environmental Health Implications of the Use and Disposal of Disposable Child Diapers in Senga/Nehosho suburbu in Gweru City, Zimbabwe. Global Journal of Biology, Agriculture and Health Sciences, 3, 122-127. 


\section{List of Abbreviations}

CANSIs: Community Acquired Needle Stick Injuries

DANIDA: Danish International Development Agency

EAs: Enumeration Areas

GSMA: Ga South Municipal Assembly

GSS: Ghana Statistical Services

HCW: Healthcare Waste

MCE: Municipal Chief Executive

NHIS: National Health Insurance Scheme

NMIMR: Noguchi Memorial Institute of Medical Research

OLS: Ordinary Least Squares Regression

SMW: Solid Medical Waste

WHO: World Health Organization 